\title{
The Effect of Public Debt on Private Consumption: The Case of Countries in Transition
}

\author{
Fisnik Morina ${ }^{\mathrm{a}^{*}}$ and Argjent Berisha ${ }^{\mathrm{b}}$ \\ a University “Haxhi Zeka”, Faculty of Business - Peja, Republic of Kosovo email: fisnik.morina@unhz.eu \\ b University “Haxhi Zeka”, Faculty of Business - Peja, Republic of Kosovo email: argjent_94@outlook.com
}

\begin{abstract}
A B S T R A C T
Developed countries have well-designed and developed economies in macroeconomic terms. However, not all countries benefit from the fruits of such an economy. Therefore, some countries are still faced with an economy that requires macroeconomic restructuring and development. People in these countries face high unemployment, evolving fiscal and monetary policies. The state is forced to borrow either internally or externally, where the latter is usually preferred. This paper aims to show the effects of government debt on private consumption with a particular focus on transition countries. Thereby explaining the factors that influence private consumption and the types of debt that governments take into account. The countries in regions, which are facing this problem, will be analysed in more detail. Kosovo is one such country, which will be analysed in detail, particularly the relationship between national debt and private consumption. This study is carried out using the statistical software STATA, whereby private consumption is a dependent variable, whilst national debt, gross fixed capital formation, foreign direct investment, consumer price index, export of goods and services and GDP growth are our independent variables. This paper is a compilation of information from multiple sources to describe the reality that transition countries are faced with when borrowing.
\end{abstract}

\author{
A R T I C L E I N F O \\ Keywords: \\ National Debt, Private Consumption, \\ Transition Countries, Gross Domestic \\ Product, Kosovo, Unemployment. \\ *Corresponding author: \\ fisnik.morina@unhz.eu \\ (Fisnik Morina)
}

Article history:

Received 23.07.2021

Revised 14.08.2021

Accepted 19.08.2021

DOI:

https://doi.org/10.51410/jcgirm.8.2.3

\section{INTRODUCTION}

This paper attempts to review a range of material from various sources to put together a compact suite of information that should guide any individual who wants to find out more about public debt as an indicator of private consumption in countries in transition. The need for this emanates from the fact that governments face various challenges, particularly those related to debt settlement, focusing on external debt. Various analyses highlight the importance of each variable that influences private consumption so that the state can take into account the influencing indicators.

As the national debt, public debt is fundamentally different from private debt since public debt is not an individual debtor. Therefore, the state as a whole bears responsibility for making decisions about public debt. Through the national debt, the state wants to regulate the economic situation of the citizens. On the other hand, consumption is the main aspect based on which the individual regulates his/her economic situation. Transition countries have a harder time paying back their debts because they face an unenviable economic situation. Private consumption as one of the main indicators of the economic development of a country should be taken into account as it is the main driver of economic growth. In this study, we attempt to understand the importance and purpose of public debt as a tool and method for economic growth, measured in terms of stimulating consumption as a key alternative to achieving macroeconomic goals. 


\section{LITERATURE REVIEW}

When a country's institutions are below a certain level of quality, higher public debt leads to slower growth (everything else being equal). However, when a country's institutions are relatively high quality, the national debt is neutral. Kourtellos et al., (2013) suggest that the government debtto-growth ratio has been significantly reduced by the quality of a country's institutions. Therefore, if a country's institutions are relatively high quality, the national debt will grow neutrally (Kourtellos, et al., 2013).

Panizza (2008), on the other hand, suggests that the traditional dichotomy between external and domestic debt doesn't make much sense in a world dominated by open equity accounts. While the recent shift to domestic borrowing has had a significant positive impact on debt management, policymakers are not very complacent (Panizza, 2008).

Woo, (2010) suggests that given the surge in a country's national debt due to the global economic and financial crisis, there are serious concerns about its further economic and financial impact on the market. In particular, some observers have pointed to the potential risk that high debt could hamper capital accumulation and slow economic growth. This can happen through higher interest rates, future higher distortion of taxes, higher inflation, greater uncertainty and macroeconomic instability (Woo, 2010).

Several empirical studies have found a link between budget deficits, money supply growth and inflation in developed and developing countries. They highlight that it is often argued that in developing countries, high inflation occurs when governments face large and persistent deficits financed by spending. In addition, overall activity can positively impact enlargement, but different sectors can develop differently. This means it will get worse for some populations. This is likely greater with rising government spending than with tax cuts. This is because changes in government purchases are more likely to focus on specific sectors of the economy (Mustafi, 2018).

Developed countries are better able than developing countries to borrow and use domestic and foreign finance productively without bearing the costs of investment barriers, capital fluctuations, and political instability and displacement that normally accompany high debt levels. In contrast, in developing countries, the negative effects of debt overlap are likely to offset the potential benefits of the availability of additional resources. The main reason for this contrasting result is poor governance and poor institutions (Presbitero, 2012 ).

Local governments must take responsibility for their financial decisions at law and their taxpayers and those of other jurisdictions. Debt is the optimal solution for funding local investments as it restores stability between decision-makers, beneficiaries and taxpayers. However, this also requires a prudent and proactive fiscal policy that measures and compares the costs and benefits for each investment project and adjusts the investment volume to the current financial strength (BeerToth, 2009 ).

Overall capital accumulation represents household wealth, disposable income and government spending has a positive long-term and short-term impact on private consumption. However, the inflation rate and real interest rate only have a positive long-term effect on private consumption. This is because disposable income, capital accumulation, government spending, inflation and the real interest rate determine the variability of private consumption in the countries in the Asia-Pacific region. In most countries, the increasing national debt has no impact on private consumption, regardless of the financing policy. The main lesson to be drawn from this finding is that governments need to balance budgetary efforts between economic activities. Countries in the Asia-Pacific region should focus on microeconomic variables to increase private consumption anddopt conscious fiscal policies (Kusairi, et al., 2019).

A country with higher unpaid government debt will have a lower equilibrium growth rate. The deleveraging leads to a higher growth rate. Borrowing does not improve welfare in the determinant model (Aizenman, et al., 2007).

In particular, Ueshina (2018) examines the impact of public debt on an economy where the budget deficit fully funds public investment. Specifically, this model shows the impact of public debt on transition dynamics if the government follows the Golden Rule of Public Finances (GRPF) rather than the Balanced Budget Rule (BBR). The first can be referred to as a threshold rather than a stable state, as it provides the amount of public capital necessary for sustainable public debt. 
Second, even when factoring-in debt-financed public investment and transition dynamics, the maximum rate of tax hike exceeds the level of the maximum welfare tax. Hence, these results also show how welfare effects can be modified depending on household characteristics and economic status when public investment is financed through a budget deficit (Ueshina, 2018).

Sutherland (1997) presented a model that shows how the influence of fiscal policy on consumption can vary depending on the level of the national debt. With moderate debt finance policies, there are traditional Keynesian effects. Current generations of consumers are deducting future taxes because they may no longer be alive at the time of the next debt stabilisation program (or, accordingly, a greater number of consumers will be available to pay taxes if a stabilisation program is in place). However, when debt levels hit the extremes, today's generation of consumers know that there is a high probability that they will stay alive if the next stabilisation program is implemented. A budget deficit can dampe consumer spending (Sutherland, 1997).

Public investment is the only type of government spending. Consequently, higher public debt, which increases the primary surplus, can only reduce productive public spending. In reality, however, other types of public spending, such as unproductive public consumption, can also be reduced. However, looking at the real-world economy, it seems that public investment is the type of expenditure that can be more easily reduced as public debt rises. This is because governments are not required to invest in public infrastructure, and there is no public investment lobby group. Hence, the decline in public investment due to growing public debt is not surprising (Greiner, 2007).

Uzun et al. (2012) noted that transition countries began to have market-oriented economies after 1991. Transition countries need external resources to change the economic structure into a marketbased economy. Problems with the connection between production marketing and sales savings increased the need for external resources. In this study, Uzun et al. (2012) analysed the relationship between GDP (gross domestic product) per capita and debt growth to GDP (gross national product) between 1991 and 2009 in transition countries. Results showed positive long-term relationships between countries' debt and growth rates.

Moreover, in an economic open market policy, the authorities in the transition countries had to account for the costs of using foreign debt. The foreign debt initially had a positive effect on the growth rate of the transition countries. Still, they had to pursue a disciplined fiscal and monetary policy and also balance the current account (Uzun, et al., 2012).

A higher national debt drives private consumption more strongly, and the extent of the accumulation effects has worsened since the global financial crisis. This could be one of the reasons for fiscal consolidation in advanced economies suffering from high public debt after the global financial crisis (Cho \& Rhee, 2013).

Based on the results of Fetai et al.'s (2020) study, we can deduce that the various sub-groups of countries in the European transformation process should design their fiscal initiative in such a way that they combat the highest levels of debt to support economic growth. Raising the highest tax level to offset debt is not a good strategy for the governments of all countries in the European transformation process, especially for low-income countries. They may need to take initiatives and other fiscal measures to stimulate the private sector as the engine of economic growth (Fetai, et al., 2020).

Jäger and Keuschnigg (2014) report some surprising results. First, increases in government debt in groups with reliable parameters can increase the well-being of future generations. Second, the admissibility of asymmetrical parameter collections makes all possible long-term welfare effects possible. The benefits of future generations can either decrease or increase in both countries or be influenced in the opposite direction. Furthermore, in small open economies, an increase in national debt can increase the human wealth of future generations if capital gains taxes are used to fund increased interest payments on the national debt (Jäger \& Keuschnigg, 2014).

Chen et al. (2016) show that the positive effects of government investment on economic growth decrease with increasing government investment, especially if the ratio of public investment/GDP is more than $20.04 \%$, after which the positive effect would be negative. Likewise, the effect of national debt on economic growth decreases when national debt increases, especially when the national debt / GDP ratio is higher than 59.72\%, after which the positive effect would turn into a negative effect. The empirical results suggest that an optimal level of government investment in terms of economic growth or an increase in the production elasticity of private capital would lead 
to a higher optimal level of public investment but a lower optimal level of public debt. Whereas an increase in the production elasticity of government investment leads to a lower optimal level of public investment but a higher optimal level of public debt (Chen, et al., 2016).

Karadam's (2018) evaluation results suggest that the non-linearity of the relationship between the debt level and growth depends mainly on the debt structure. Essentially, Karadam's (2018) results show that total public debt, short-term external debt, and long-term external public debt have the largest effects from raising the threshold. The growth effects of these debt components are very negative when debt levels are high. In addition, the public debt thresholds for developing countries are lower than for developed countries, which means that these economies need to be more careful with their public debt (Karadam, 2018 ).

Saungweme and Odhiambo's (2019) study shows that the impact of public debt on economic growth is not given and varies depending on some heterogeneous factors. These include the level of development of the countries studied, the institutional quality, the relative size of the public sector, the composition and the structure of government debt, the data sets and the research methodology used as well as the selected control variables, in the context of the other factors. Their study concludes that the impact of public debt on economic growth is not clear and that the notion of public debt is a negative phenomenon for economic growth as many scientific studies in recent years have provided such empirical evidence. (Saungweme \& Odhiambo, 2019).

Kwon et al. (2009) emphasise the importance of institutional and structural factors in the relationship between debt and inflation, such as fiscal rules, inflation targets, and the depth and breadth of the financial sector. They also show that, despite the important role of monetary policy in steering inflation expectations, fiscal policy is likely to be the dominant driver of inflation in heavily indebted developing countries. This means that price stability, achieved mainly through the issuance of central bank open market instruments (i.e. the accumulation of sovereign debt) instead of monetising the deficit, can only be sustained if supported by fiscal consolidation and structural reforms to strengthen monetary independence (Kwon, et al., 2009).

A state can be solvent in the sense that it can generate enough income in the future to pay off the debt service, but it can become illiquid if it cannot enter the financial markets on reasonable terms when the old debts fall due. High-risk premiums drive up interest rates, a liquidity crisis can turn into a solvency crisis. Our analysis emphasises that the trend and the level of the debt ratio should be an important indicator. However, our analysis suggests that a government debt benchmark of $60 \%$ of GDP can be used flexibly to trigger the benchmark for debt limit analysis. The government should aim to cover the budget balance and national debt as much as possible, paying special attention to companies with significant tax risks, including state-owned companies and corporations, public-private partnerships, and pensions and health (Chitiga, 2014 ).

Sulejmani and Ademi (2019) empirically analyse the effects of public debt on economic growth and the policies that influence economic growth in the European transition countries from 1996 to 2017. Given the attention of many scholars and the importance of politics to national debt and economic growth, we have empirically investigated the relationship of these two variables in European transition countries and based on our knowledge. This is the first contribution that attempts to apply these techniques empirically for this group of countries to determine national debt ratios and economic growth. Public debt has a positive but insignificant impact on GDP per capita. Consumption has a positive and statistically significant effect on GDP per capita. The gross savings have a positive impact on GDP per capita. Fixed investment with a positive statistically significant coefficient positively affects GDP per capita. However, the positive government spending ratiolaims a negligible effect on GDP per capita GDP (Sulejmani \& Ademi, 2019).

The record increase in public debt as a percentage of GDP in the transition period is due to a strong increase in social spending without a simultaneous increase in tax revenue. To ensure the sustainability of public debt and the credibility of Romania's economy for the future, a better correlation is needed between some basic macroeconomic indicators and the inclusion of pressure from international financial institutions, as seems to be the trend in recent years (Albu \& Pelinescu, 2000).

Empirical results by Časni et al. (2014) indicate a negative correlation between government debt and growth control for other growth determinants (opening of trade, value-added by industry and total investment). As the crisis unfolded in Central, Eastern and South-eastern Europe, the rapid 
decline in production wasollowed by an increase in government spending and a decrease in government revenue, which led to an increase in the public deficit (Časni, et al., 2014).

There is a negative relationship between public debt and investment in the long run. Since there is a direct relationship between investment and economic growth and an inverse relationship between economic growth and public debt. However, public debt must be managed and kept under control, as high debt levels would have negative long-term effects, and the later phase of borrowing, which is characterised by high levels of debt, will lead to low growth (Thobeka \& Marius, 2018).

The impact on the GDP growth rate is the most important factor in stabilising and reducing national debt in the new member states of Central and Eastern Europe. Active and direct management of national debt through budget consolidation and austerity measures can have a negative impact on GDP, especially in the short term, and thus increase the national debt, which has the opposite effect of the desired one (Pečarić, et al., 2018).

According to Matiti (2013 ), Kenya's domestic debt was stable. Contingent liabilities pose a potential risk and burden to the national budget and a risk to domestic debt sustainability. Therefore, the government should develop a framework for the recording and monitoring of all contingent liabilities and formulate and implement a guideline for contingent liability management. Regular reporting on outstanding debts will also ensure transparency for the public and donor countries in managing these debts (Matiti, 2013 ).

After reviewing the literature and the results of Kadia's (2020) empirical analysis, it can be noted that there is a statistically very non-linear relationship between national debt and economic growth and that corruption is strongly correlated with a country's economic growth. In addition, Kadia's (2020) analysis has shown that, on the one hand, public debt can be detrimental to economic growth due to its costs. On the other hand, when debt is used to increase a country's productivity to pay off previous debts with income, debt can positively impact the economy. Albania is a country in need of a reduction in its debt ratio / GDP. This can be done through an economic stimulus rather than a reduction in public debt (Kadia, 2020 ).

Ntshakala's (2015) preliminary aim of the study was to measure the impact of domestic debt on economic growth in Swaziland. The results showed that domestic debt is an important determinant of economic growth, so an increase in domestic debt will fuel the country's economic growth. This means that domestic debt positively impacts Swaziland's economic growth. Domestic government borrowing can be increased to fund investment growth, as this study has shown that an increase in changing domestic borrowing leads to an improvement in the country's economy. The country still has leeway for loans if those loans flow into growth-promoting projects (Ntshakala, 2015 ).

According to Cano (2020), Albania is a country in need of a reduction in its debt-to-GDP ratio. In Cano's (2020) view, this can be done through an economic incentive rather than a reduction in public debt. Empirical analysis showed that the increase in real government debt could have a negative impact on GDP, but observations showed no specific level at which the effects worsened. Instead, government debt rose, the cost of debt sometimes went down because governments replaced debt borrowed from commercial banks with debt from the IMF. Investing in sectors such as agriculture would prepare the country for more competitive products, while neighbouring countries have lost some of their competitive advantages due to the current economic crisis. So if the government were to borrow to invest in agriculture technology or education to increase human capital productivity, that debt would increase a country's overall productivity and wages and, later, positively affectonsumption (Cano, 2020).

Simović (2018) concluded that fiscal instability and the rise in public debt were similarly influenced by negative economic trends and a lack of financial regulation, as well as the deterioration in financing and the rise in interest rates during the recession. The empirical results confirmed the thesis that the level of national debt significantly influences and reduces the effectiveness of fiscal policy (Šimović, 2018 ).

\section{RESEARCH METHODOLOGY}

We collected our data from publications by the Central Banks of 22 transition countries, the World Bank, the International Monetary Fund, the European Central Bank. The analysis was carried out using Microsoft Office Excel and STATA software. Four empirical were used to measure the 
empirical results; specifically, a) Linear Regression; b) Fixed Effect; c) Random Effect and d GMM Model

Our sample consisted of European countries, which are in the process of transition. We made this selection based on official reports of the World Bank and the International Monetary Fund. The sample includes 22 European countries during six years between 2014 and 2019. In the sample chosen, we included 11 European countries that completed the transition phase in 2019. These are specifically: Bulgaria, Croatia, Czech Republic, Estonia, Hungary, Latvia, Lithuania, Poland, Romania, Slovakia and Slovenia.

The data collection was carried out in three phases. In the first phase, we have referred to studies by other authors who have analysed the impact of public debt on private consumption in different parts of the world. Through these reviews, we defined the study variables, which served for our economic measurement and the processing of the econometric results. In the second phase, after defining the variables of this study and selecting the sample, we started collecting the statistical data from the annual macroeconomic reports of the World Bank and the International Monetary Fund. In the final phase, we processed the data, coded it, and carried out the statistical data calculations using the Stata program. We then continued to extract the econometric results and analyse the findings of this study.

\section{EMPIRICAL DATA ANALYSIS AND ECONOMETRIC RESULTS}

The following table presents the data for descriptive statistics, including all the variables of this study. These descriptive statistics include the number of observations, the minimum and maximum values, the mean, the standard deviation and the variance.

Table 1: Statistics descriptive

\begin{tabular}{|l|c|c|c|c|c|c|}
\hline Variables & N & Minimum & Maximum & Mean & $\begin{array}{c}\text { Std. } \\
\text { Deviation }\end{array}$ & Variance \\
\hline $\begin{array}{l}\text { Final } \\
\text { consumption } \\
\text { costs }\end{array}$ & 132 & -1.404 & 107.138 & 78.34047 & 19.84033 & 393.6387 \\
\hline $\begin{array}{l}\text { General } \\
\text { government } \\
\text { debt }\end{array}$ & 111 & -1.404 & 83.993 & 46.17059 & 22.11096 & 488.8946 \\
\hline $\begin{array}{l}\text { Gross fixed } \\
\text { capital } \\
\text { formation }\end{array}$ & 130 & 13.549 & 33.224 & 21.82301 & 3.516655 & 12.3669 \\
\hline $\begin{array}{l}\text { Foreign direct } \\
\text { investments }\end{array}$ & 132 & -41.508 & 54.649 & 3.893826 & 6.754075 & 45.6175 \\
\hline $\begin{array}{l}\text { Consumer } \\
\text { price index }\end{array}$ & 131 & -1.584 & 48.7 & 2.641275 & 5.271673 & 27.7905 \\
\hline $\begin{array}{l}\text { Export of } \\
\text { goods and } \\
\text { services }\end{array}$ & 132 & 21.937 & 96.216 & 55.2262 & 19.56827 & 382.9172 \\
\hline \begin{tabular}{l} 
GDP growth \\
\hline
\end{tabular} & 132 & -9.773 & 7.6 & 3.097795 & 2.123581 & 4.5096 \\
\hline
\end{tabular}

Based on the descriptive results presented in Table 1, we can conclude that the highest value of standard deviation belongs to the following variables: general government debt, final consumption costs and export of goods and services. The variables, which have the lowest standard deviation value, are gross fixed capital formation, foreign direct investment, consumer price index, and GDP growth. Therefore, the variables, which have a higher value of standard deviation, indicating that the data is more prevalent than the average value, while the variables, which have a lower value of standard deviation, are considered to be distributed closer to the average value. 
Table 2: Correlation analysis

\begin{tabular}{|l|c|c|c|c|c|c|c|}
\hline Variables & $\begin{array}{c}\text { Final } \\
\text { consumptio } \\
\text { n } \\
\text { Costs }\end{array}$ & $\begin{array}{c}\text { General } \\
\text { governme } \\
\text { nt debt }\end{array}$ & $\begin{array}{c}\text { Gross } \\
\text { fixed } \\
\text { capital } \\
\text { formatio } \\
\mathbf{n}\end{array}$ & $\begin{array}{c}\text { Foreign } \\
\text { direct } \\
\text { investments }\end{array}$ & $\begin{array}{c}\text { Consumer } \\
\text { price } \\
\text { inflation }\end{array}$ & $\begin{array}{c}\text { Export of } \\
\text { goods and } \\
\text { services }\end{array}$ & $\begin{array}{c}\text { GDP } \\
\text { growth }\end{array}$ \\
\hline $\begin{array}{l}\text { Final } \\
\text { consumption } \\
\text { costs }\end{array}$ & 1 & 0.3886 & 0.1714 & 0.1093 & 0.0528 & -0.1869 & -0.1669 \\
\hline $\begin{array}{l}\text { General } \\
\text { government } \\
\text { debt }\end{array}$ & 0.3886 & 1 & -0.2109 & 0.0826 & 0.1626 & 0.1724 & -0.2828 \\
\hline $\begin{array}{l}\text { Gross fixed } \\
\text { capital } \\
\text { formation }\end{array}$ & 0.1714 & -0.2109 & 1 & 0.0003 & -0.0799 & -0.0216 & 0.1985 \\
\hline $\begin{array}{l}\text { Foreign direct } \\
\text { investments }\end{array}$ & 0.1093 & 0.0826 & 0.0003 & 1 & -0.0372 & -0.1082 & -0.0518 \\
\hline $\begin{array}{l}\text { Consumer price } \\
\text { inflation }\end{array}$ & 0.0528 & 0.1626 & -0.0799 & -0.0372 & 1 & -0.0724 & -0.5888 \\
\hline $\begin{array}{l}\text { Export of goods } \\
\text { and services }\end{array}$ & -0.1869 & 0.1724 & -0.0216 & -0.1082 & -0.0724 & 1 & 0.0213 \\
\hline GDP growth & -0.1669 & -0.2828 & 0.1985 & -0.0518 & -0.5888 & 0.0213 & 1 \\
\hline
\end{tabular}

According to the correlation results, there is a weak and positive correlation of 0.3886 between government debt and consumer spending. If the national debt increases by $38.86 \%$, consumer spending increases and vice versa. There is a weak and positive correlation of 0.1714 between gross fixed capital formation and consumer spending. This means that if gross fixed capital formation increases by $17.14 \%$, consumer-spending increases and vice versa. There is a weak and positive correlation of 0.1093 between FDI and consumer spending, which means that if FDI increases by $10.93 \%$, consumer spending increases and vice versa. There is a weak and positive correlation of 0.0528 between the consumer price index and consumer spending. This means that if the consumer price index increases by $5.28 \%$, consumer-spending increases and vice versa.

There is a weak and negative correlation of -0.1869 between exports of goods and services and consumer spending. This means that if the export of goods and services falls by $-18.69 \%$, consumer spending falls and vice versa. There is a weak and negative correlation of -0.1669 between GDP growth and consumer spending. This means that if GDP growth declines by $-16.69 \%$, consumer spending will decrease and vice versa.

The equation used in this paper is:

$$
\mathrm{Yt}=\mathrm{b0}+\mathrm{b} 1 \mathrm{X} 1+\mathrm{b} 2 \mathrm{X} 2+\mathrm{b} 3 \mathrm{X} 3+\mathrm{b} 4 \mathrm{X} 4+\mathrm{b} 5 \mathrm{X} 5+\mathrm{b} 6 \mathrm{X} 6
$$

$Y_{t}$ (Final consumption costs) $=b_{1} X_{1}$ (General Government Debt) $+b_{2} X_{2}$ (Gross Fixed Capital Formation) $+b_{3} X_{3}$ (Foreign Direct Investment) $+b_{4} X_{4}$ (Consumer Price Index) $+b_{5} X_{5}$ (Export of Goods and Services $)+b_{6} X_{6}(G D P$ growth $)+\varepsilon$

$\mathbf{Y}_{\mathbf{t}}$ - represents the dependent variable (the variable that is being explained). In our research case, the dependent variable is consumption costs.

$\mathbf{b}_{\mathbf{0}}, \mathbf{b}_{1}, \mathbf{b}_{2}, \mathbf{b}_{3}, \mathbf{b}_{4}, \mathbf{b}_{5}$ and $\mathbf{b}_{6}$ are defined as evaluation parameters or coefficients, where $b_{0}$ is the constant parameter while $\mathbf{b}_{\mathbf{1}}, \mathbf{b}_{\mathbf{2}}, \mathbf{b}_{\mathbf{3}}, \mathbf{b}_{\mathbf{4}}, \mathbf{b}_{\mathbf{5}}$ and $\mathbf{b}_{\mathbf{6}}$ are the independent variables evaluation parameters.

$\mathbf{X}_{\mathbf{1}}-\mathbf{X}_{\mathbf{6}}$ - represents the independent variables. In our case, the independent variables are general government debt, gross fixed capital formation, foreign direct investment, consumer price index, exports of goods and services and GDP growth.

PAGE 31| Journal of Corporate Governance, Insurance, and Risk Management | 2021, VOL. 8, Series. 2 
$\boldsymbol{\varepsilon}$ - is the term of the statistical variable or error. This contains all the factors or variables that are not predicted in the model and is a random and unprotected variable that captures positive and negative values. The statistical error indicates that other factors affect the dependent variable consumer spending. This indicates that the complete variable is not explained or does not give us information from the independent variables. Otherwise, the statistical component represents the unexplained part of the model.

Table 3: Econometric Results

\begin{tabular}{|c|c|c|c|c|}
\hline Variables & $\begin{array}{c}\text { Linear } \\
\text { Regression }\end{array}$ & $\begin{array}{l}\text { Fixed - Effects } \\
\text { Regression }\end{array}$ & $\begin{array}{c}\text { Random } \\
\text { Effects - GLS } \\
\text { Regression }\end{array}$ & GMM Model \\
\hline Final consumption costs & - & - & - & $\begin{array}{l}0.2771462 \\
(0.105)\end{array}$ \\
\hline General government debt & $\begin{array}{l}0.4470887 \\
(0.000)\end{array}$ & $\begin{array}{l}-0.0221073 \\
(0.638)\end{array}$ & $\begin{array}{l}-0.0006407 \\
(0.989)\end{array}$ & $\begin{array}{c}-0.046099 \\
(0.309)\end{array}$ \\
\hline $\begin{array}{l}\text { Gross fixed capital } \\
\text { formation }\end{array}$ & $\begin{array}{l}1.698857 \\
(0.001)\end{array}$ & $\begin{array}{l}-0.5221767 \\
(0.000)\end{array}$ & $\begin{array}{l}-0.5005291 \\
(0.000)\end{array}$ & $\begin{array}{l}-0.4013045 \\
\quad(0.004)\end{array}$ \\
\hline Foreign direct investments & $\begin{array}{l}0.0895719 \\
(0.712)\end{array}$ & $\begin{array}{l}-0.0056275 \\
(0.810)\end{array}$ & $\begin{array}{l}-0.0054579 \\
(0.817)\end{array}$ & $\begin{array}{l}0.0076571 \\
(0.698)\end{array}$ \\
\hline Consumer price index & $\begin{array}{l}-0.3865401 \\
(0.313)\end{array}$ & $\begin{array}{c}-0.0693754 \\
(0.172)\end{array}$ & $\begin{array}{l}-0.0720413 \\
(0.155)\end{array}$ & $\begin{array}{l}0.0764958 \\
(0.162)\end{array}$ \\
\hline $\begin{array}{l}\text { Export of goods and } \\
\text { services }\end{array}$ & $\begin{array}{l}-0.2812974 \\
(0.002)\end{array}$ & $\begin{array}{c}-0.3747793 \\
\quad(0.000)\end{array}$ & $\begin{array}{l}-0.3623835 \\
(0.000)\end{array}$ & $\begin{array}{l}-0.2944557 \\
(0.002)\end{array}$ \\
\hline GDP growth & $\begin{array}{c}-1.350885 \\
(0.173)\end{array}$ & $\begin{array}{c}-0.0502668 \\
(0.641)\end{array}$ & $\begin{array}{c}-0.0502784 \\
(0.641)\end{array}$ & $\begin{array}{l}0.1558184 \\
(0.178)\end{array}$ \\
\hline Const. & $\begin{array}{c}40.57312 \\
(0.003)\end{array}$ & $\begin{array}{c}111.0208 \\
(0.000)\end{array}$ & $\begin{array}{c}109.6636 \\
(0.000)\end{array}$ & $\begin{array}{c}81.94796 \\
(0.000)\end{array}$ \\
\hline R Square & 0.7015 & 0.7270 & 0.7353 & - \\
\hline
\end{tabular}

$\mathbf{H}_{\mathbf{1}}$ - General government debt affects final consumption expenditures.

(Here, we can see that general government debt does not affect final consumption expenditures because general government debt is not intended for consumption but other investments. The hypothesis, in this case, is refuted).

$\mathbf{H}_{2}$ - gross fixed capital formation affects consumer spending. Here we see that gross fixed capital formation has an impact on consumer spending since domestic investment is also intended for consumption. The hypothesis is accepted.

$\mathbf{H}_{3}$ - Foreign direct investment affects consumer spending. Here we see that FDI has no impact on consumer spending, as the FDI does not serve to support final consumption but other investments. The hypothesis is rejected.

$\mathbf{H}_{\mathbf{4}}$ - consumer price index affects consumer spending. Here we see that the consumer price index does not affect consumer spending, which means that inflation has been kept at a constant level, which has not affected final consumption. The hypothesis is rejected.

$\mathbf{H}_{5}$ - Exports of goods and services affect consumer spending. Here we can see that the export of goods and services affects consumer spending since exports are one of the indicators of the economic 
development of countries and especially countries in transition and the growth of the trade balance. The hypothesis, in this case, is accepted.

$\mathbf{H}_{6}$ - GDP growth affects consumer spending. Here we see that GDP growth does not affect consumer spending. Although GDP is an indicator showing the country's macroeconomic growth, in our case, it has no impact on consumer spending growth. The hypothesis is rejected.

\section{DISCUSSION}

Referring to the econometric results, it can be concluded that public debt has not affected private consumption in transition countries. This result is contrary to the economic theory that public debt affects private consumption. Given the fact that in low-debt economies, the level of public debt is not significant for private consumption, then the insignificant impact of public debt on private consumption in transition countries is acceptable and can be argued with empirical evidence.

Countries in transition (22 countries) for the period analysed (2014 - 2019) have an average value of public debt of $46.17 \%$, a value which is not very high for these countries. Therefore, since these countries have a low level of public debt, the effect of this debt on private consumption is not significant. In countries with high debt levels, the level of public debt has a negative impact on private consumption since a fiscal expansion will be partially offset by private consumption.

The results of this study contradict the study of authors such as Cho and Rhee (2013), who analysed the non-linear effect of public debt on private consumption in OECD countries. This study shows that a higher level of government debt encourages more private consumption. Such a hypothesis applies to OECD countries, but our study highlights an insignificant impact of public debt on private consumption for transition countries. In addition, the results of this study contradict the findings of the study of the authors such as Berben and Brosens (2007). Therefore, this study shows that the correlation between government debt and private consumption in OECD countries is non-linear. Based on these results, it can be concluded that fiscal policies may be less effective in stabilising fluctuations in business cycles in countries with high government debt. Therefore, the empirical findings of our study are comparable to the results of the study by Kusairi et al. (2019), who note that the overall results of this study show that public debt does not affect private consumption in Asia - Pacific countries in the short and long term.

\section{CONCLUSIONS AND RECOMMENDATIONS}

One of the pillars of the state is to increase social welfare. It has to maintain this welfare and is obliged to ensure that these debts are thought through in detail and planned for the longer term.

This type of problem that every developed or under-developed state faces differs in the way that states deal with it. For example, the Maastricht Treaty predicts what the optimal level of debt will have to be to achieve stable economic growth. Based on our empirical findings, we can conclude that when the institutions of a state are weak, the national debt has a minimal effect on economic growth, whereas if the institutions of a state are developed, the national debt has a neutral effect on economic growth. As we note in the literature review, some authors concluded that developed countries are better able to manage public debt than developing countries because the latter suffers from poor management.

Public debt in the Western Balkans continues to be one of the main topics of discussion when focussing on EU integration. However, Western Balkans countries are characterised by stable budget levels despite their high national debt. High public spending and household borrowing have driven consumption growth.

Based on the results, we can see that only the variables gross fixed capital formation and exports of goods and services are significant and thus have an impact on consumer spending. Thus, the formation of gross fixed capital influenced the final consumption of consumers and other variables such as the export of goods and services influenced GDP growth and, at the same time, the growth of final consumption. 


\section{REFERENCES}

Aizenman, J., Kletzer, K. \& Pinto, B. 2007. Economic Growth With Constraints On Tax Revenues And Public Debt: Implications For Fiscal Policy And Cross-Country Differences. National Bureau of Economic Research, pp. 21-30.

Albu, L. L. \& Pelinescu, E. 2000. Sustainability of public debt: a theoretical and empirical investigation. MPRA Paper, pp. 24-29.

Beer-Toth, B. D. a. K. 2009. Managing Local Public Debt in Transition Countries: An Issue Of SelfControl. John Wiley \& Sons, Inc., pp. 20-29.

Berben, R. P. \& Brosens, T. 2007. The impact of government debt on private consumption in OECD countries. Economics Letters, Volume 94, pp. 220-225.

Cano, A. 2020. Evolution of Public Debt in Albania during 1990-2017 and its impact on the Economic Growth. European Journal of Marketing and Economics, pp. 6-8.

Časni, A. Č., Badurina, A. A. \& Sertić, M. B. 2014. Public debt and growth: evidence from Central, Eastern and Southeastern European countries. Journal of Economics and Business Elsevier BV, pp. 12-17.

Chen, C., Yao, S., Hu, P. \& Li, Y. 2016. Optimal government investment and public debt in an economic growth model. China Economic Review Elsevier BV, pp. 37-53.

Chitiga, M. R. M. H. M. 2014. Real Effects of Public Debt on National Development. Purdue University, West Lafayette, IN: Global Trade Analysis Project (GTAP), pp. 54-57.

Cho, D. \& Rhee, D.-E. 2013. Non-linear effects of government debt on private consumption: Evidence from OECD countries. Economics Letters Elsevier B.V, pp. 4-4.

Fetai, B., Avdimetaj, K., Bexheti, A. \& Malaj, A. 2020. Threshold effect of public debt on economic growth: An empirical analysis in the European transition countries. Original scientific paper, pp. 17-26.

Greiner, A. 2007. An Endogenous Growth Model with Public Capital and Sustainable Government Debt. The Japanese Economic Review, pp. 16-17.

Jäger, A. \& Keuschnigg, C. 2014. The Burden of Public Debt in Open Economies. FinanzArchiv / Public Finance Analysis Mohr Siebeck GmbH \& Co. KG, pp. 19-22.

Kadia, A. 2020. Public Debt and Economic Growth in the Balkan Countries. European Journal of Economics and Business Studies, pp. 6-7.

Karadam, D. Y. 2018. An investigation of non-linear effects of debt on growth. Journal Of Economic Asymmetries, 18, 1-13. doi: 10.1016/j.jeca.2018.e00097

Kourtellos, A., Stengos, T. \& Tan, C. M. 2013. The effect of public debt on growth in multiple regimes. Journal of Macroeconomics Elsevier, p. 7.

Kusairi, S., Maulina, V. \& Margaretha, F. 2019. Public debt and private consumption in Asia Pacific countries: Is there evidence for Ricardian equivalence?. Journal of International Studies, pp. 1315.

Kwon, G., McFarlane, L. \& Robinson, W. 2009. Public Debt, Money Supply, and Inflation: A CrossCountry Study. IMF Staff Papers, pp. 29-41.

Matiti, C. 2013 . The relationship between public debt and economic growth in Kenya. International Journal of Social Sciences and Project Planning Management , pp. 17-21 .

Mustafi. M. \&. Karemani, S. M. 2018. Empirical Studies Analysing the Dynamic Effects of Changes in Public Spending and Taxation on Activities. KNOWLEDGE - International Journal, pp. 16451646.

Ntshakala, P. L. 2015 . Effects of public debt on economic growth in Swaziland. International Journal of Business and Commerce, pp. 20-24 .

Panizza, U. 2008. Domestic and external public debt in developing countries. SSRN Electronic Journal , p. 14.

Pečarić, M., Slišković, V. \& Kusanović, T. 2018. Public debt in new EU member states - Panel data analysis and managerial implications. MANAGEMENT - Journal of Contemporary Management Issues, pp. 12-18.

Presbitero, A. F. 2012 . Total Public Debt and Growth in Developing Countries. European Journal of Development Research , pp. 618-621.

Saungweme, T. \& Odhiambo, N. M. 2019. The Impact of Public Debt on Economic Growth: A Review of Contemporary Literature. SAGE Journals The Review of Black Political Economy, pp. 15-19.

PAGE 34| Journal of Corporate Governance, Insurance, and Risk Management | 2021, VOL. 8, Series. 2 
Šimović, H. 2018 . Impact of public debt sustainability on fiscal policy in Croatia. Acta Oeconomica, pp. 11-14

Sulejmani, L. A. \& Ademi, A. 2019. Does Public Debt Hamper Economic Growth: Evidence From European Transitional Countries. KNOWLEDGE -International Journal, pp. 5-6.

Sutherland, A. 1997. Fiscal crises and aggregate demand: can high public debt reverse the effects of fiscal policy?. Journal of Public Economics Elsevier BV, pp. 14-16.

Thobeka, N. \& Marius, M. M. 2018. Can public debt stimulate public investment and economic growth in South Africa. Cogent Economics \& Finance, pp. 21-27.

Ueshina, M. 2018. The effect of public debt on growth and welfare under the golden rule of public finance. Journal of Macroeconomics Elsevier BV, pp. 28-34.

Uzun, A., Karakoy, C., Kabadayi, B. \& Emsen, O. S. 2012. The Impacts of External Debt on Economic Growth in Transition Economies. David Publishing Company. pp. 8-9.

Woo, M. S. K. a. J. 2010. Public Debt and Growth. IMF Working Paper, p. 21. 